shape of the scutellum and is more closely allied to Botanobia than to Gaurax, differing from it principally in the distinctly pubescent arista.

Chaetochlorops, n. gen.

The type of this genus is Siphonella infuilina Coquillett. The characters given in the foregoing table should suffice for its identification. This is the only species I know which is referable to this genus.

The other changes in generic names I have already dealt with in the Canadian Entomologist, 1913, p. 175.

\title{
A PHALANGID DRINKS MILK.
}

I generally have a cup of milk placed in my room, which I drink after I have finished my nocturnal rounds of my treacled trees.

The other night I saw a very fine specimen of a Harvestman (Phalangid) in the saucer. Wondering what brought him there, I managed to remove the cup without disturbing him, and found that a small quantity of milk had been spilt into the saucer and that the spider was taking a drink.

He first anchored his fourth pair of legs on the rim of the saucer; then gradually-very slowly-lowered his body till it was nearly touching the liquid. It was then tipped forward and downwards, until the mouth was in contact with the milk. After about a minute he raised himself to his ordinary standing height and began to clean his mouth, opening and shutting his mandibles (or whatever they are) like a pair of compasses. I was surprised at their size -far larger and more formidable looking than one expects from the size of the creature. Then he raised one or other of his second pair of legs and used the claw to finish the cleaning process. This done to his satisfaction he took another drink. This he did three successive times, and then, satisfied I suppose, took his departure. I noticed he was most careful to keep his feet out of milk.---E. Firmstone Heath,

The Hermitage, near Cartwright, Man.

September 6th, 1913. 